\title{
Sustainability reporting among Swedish tourism service providers: information differences between them
}

\author{
A. Sörensson \& A.-M. Jansson \\ Mid Sweden University, Sweden
}

\begin{abstract}
Within the tourism industry, there is considerable focus on sustainable tourism and the fact that tourism service providers should be sustainable. One way for tourism service providers to address these issues and communicate their sustainability work is for instance through annual reports, sustainability reports and home pages. The aim with this study was therefore to explore and compare what kind of information concerning sustainability that Swedish tourism service providers present to stakeholders. A sustainability report is one way for tourism companies to be more legitimate and accountable toward their stakeholders. Data was collected from 60 tourism service providers (e.g. 20 hotels, 20 restaurants and 20 activity companies) in Sweden from their annual reports and sustainability reports as well as their home pages. They are large-sized tourism service providers with a yearly turnover of between 5 and 50 million euros. The result shows that very few companies make sustainability reports. There is also a difference between how and where they present their sustainability work. The companies often present more of their sustainability work on their homepage compared to in annual and sustainability reports. The conclusion is that hotels are more focused on environmental sustainability, restaurants are focused more on social sustainability and the activity companies have little information about their sustainability work. Keywords: sustainability report, tourism service providers, hotels, restaurants, environmental sustainability, economic sustainability, social sustainability.
\end{abstract}

\section{Introduction}

Sustainable tourism has been on the agenda since the publication of the Brundtland Commission Report [1] but progress has been slow. Tourism is the largest industry 
in Europe and is growing steadily but the resources are limited. In the Brundtland Commission Report, it was stated that "Sustainable development is development that meets the needs of the present without compromising the ability of future generations to meet their own needs". Sustainable development is mainly discussed with the focus on three dimensions; economic, social, and environmental sustainability. As a result from the Brundtland report, companies started in the early 1990s to present environmental reports and in the mid-1990s social reports. Since the beginning of early 2000 sustainability reports were introduced that included all three sustainability dimensions; economic, social and environmental. "Sustainability reporting is the practice of measuring, disclosing, and being accountable to internal and external stakeholders for organizational performance towards the goal of sustainable development" [2]. Previous research has shown that companies' reasons for sustainability reporting varies and is often unclear [3]. This might be due to a lack of clear framework. There are differences between what companies choose to include, and also if they do it for "greenwashing" which means that they do it for the sake of the stakeholders rather than to be "good". Today, companies are trying to report more information than traditional financial accounting [4]. Sweeney and Coughlan [5] argue that sustainability reporting is used to satisfy stakeholders, show accountability and legitimacy and also as a way of communicating with their stakeholders.

The Global Reporting Initiative (GRI) is a framework for companies on how to create sustainability reports with focus on how a company influences from both an economic, a social and an environmental perspective. Starting in 2017, an EUdirective will mandate that all companies that fulfils two of the following three criteria to report sustainability. They must have more than 250 employees, a yearly turnover over 35 million euro and total assets of 17, 5 million euro. Until then, the sustainability report is a voluntary act of privately owned companies. There is no requirement for private companies to report sustainability and no mandatory framework. Several national and international institutions have developed their own guidelines for sustainability reporting, but GRI is one of the most well-known [6]. Since companies can choose how they want to present their sustainability work, there are many that uses it more for marketing reasons rather than for evaluation. Different stakeholders like employees, customers, suppliers, creditors and public authorities are pursuing different economic, social and environmental issues that determines the success of a company [7-9]. Companies can try, through sustainability reporting, to meet these demands by presenting information with the goal to increase transparency, improve brand value, reputation and legitimacy, motivate employees and contributing to corporate sustainability [10]. The aim with this study is therefore to explore and compare what kind of information concerning sustainability that Swedish tourism service providers' present to stakeholders. The research aim will be further explored through the following research questions:

RQ1: What kind of sustainability factors are addressed by tourism service providers in information to their stakeholders? 
RQ2: Is there a difference among different types of tourism service provider in what kind of sustainability factors that they address in their communication about sustainability?

\section{Theoretical framework}

\subsection{Sustainable tourism}

Sustainable tourism is a well-established research field but there is still no generally accepted definition of the concept [11]. Sustainability as a concept can be connected to all kinds of tourism and environments but the problem is how the concept should be used in a practical and useful way [12-17]. In tourism research, the principle of sustainable tourism is well discussed in consensus but among tourism service providers the real implementation is limited. The reason for this is that tourism service providers are willing to apply the concept only if there is a benefit. They use sustainable tourism if it helps them to increase their revenues and improve their public relations. There are only a few tourism service providers who have a genuine commitment to environmental sustainability. By investing in energy saving and water reduction systems, tourism service providers could see sustainability as a way of saving money. If hotels do not have to wash the towels every day it will save the hotel money in the long run. Indisputably, tourism has environmental impacts on a destination since the tourists are consumers of the environment since they have travelled to the destination to consume it [18]. At many destinations the tourism development has been rapid and often unplanned. For tourism service providers, sustainable tourism might be a tool for tourism development, particularly regarding the economic factors. There will not be any tourism without economic sustainability since tourism service providers must be able to earn their living on the income from tourists. This is also related to the issue of social sustainability. There must be tourism service providers and their employees at a destination to take care of the tourists. Sustainable tourism is therefore tourism which relies on a destination's economic, social and environmental conditions. There cannot just be a focus on high income and high revenues but also a focus on environmental issues since there is a carrying capacity of nature and a social aspect that must be addressed when discussing sustainable tourism [19].

\subsection{Sustainable reporting}

When sustainable tourism is discussed, the issue of sustainability reporting becomes relevant to discuss and also to raise the question on how sustainability reporting should be practiced. There are several organization that tries to standardize sustainability reporting. One of the most used is Global Reporting Initiatives (GRI). GRI was founded in 1997 by a non-governmental organization. GRI is a common used framework with the purpose of supporting companies to create sustainability reports that includes economic, social and environmental impact of their business. Elkington [20] argue that a company should not just focus 
on revenue but also include social and environmental values. The triple bottom line is based on the three dimension of sustainability; economic, social and environmental sustainability. GRI argues that sustainability reporting is not onesize-fits-all and therefore allows companies to choose between to different options; core or comprehensive. Companies should choose the one that best meets their need and their stakeholders. It is not a matter of quality of the report or the performance but rather degree of applied guidelines [21]. GRI argues for that companies take the stakeholders into account and report relevant information. The framework of GRI could be summarized in this simplified model (see Table 1).

Table 1: The sustainability dimensions of GRI.

\begin{tabular}{|l|l|l|}
\hline \multicolumn{3}{|c|}{ Sustainability reporting (GRI) } \\
\hline \multicolumn{1}{|c|}{ Economic } & \multicolumn{1}{|c|}{ Social } & \multicolumn{1}{c|}{ Environmental } \\
\hline Economic results & Employment & Material \\
\hline Market presence & $\begin{array}{l}\text { Relation between } \\
\text { employees and } \\
\text { management }\end{array}$ & Energy \\
\hline $\begin{array}{l}\text { Indirect economic } \\
\text { impact }\end{array}$ & $\begin{array}{l}\text { Health and security in } \\
\text { work }\end{array}$ & Water \\
\hline & Education & Biological diversity \\
\hline & Diversity and equality & $\begin{array}{l}\text { Emission (air, water } \\
\text { and waste) }\end{array}$ \\
\hline & & Products and services \\
\hline & & Compliance \\
\hline & & $\begin{array}{l}\text { Transport } \\
\text { envestments for } \\
\text { protection }\end{array}$ \\
\hline & & \\
\hline
\end{tabular}

\subsection{Legitimacy}

There is research that shows that sustainability reporting is more a symbolic act to gain legitimacy [22]. Legitimacy is the acceptance by society of the behaviours of the company. Suchman [23, p. 574] defines legitimacy as "a generalized perception or assumption that the actions of an entity are desirable, proper, or appropriate within some socially constructed system of norms, values, beliefs, and definitions". The issue is therefore to gain acceptance by society of the behaviours of the company [23]. Companies that have a low environmental performance is affecting their legitimacy status [24]. For companies it is crucial both to gain and maintain legitimacy from stakeholder in society [25]. From this perspective sustainability reporting give the companies the possibility to communicate to the stakeholders. If a company has negative experiences the legitimacy could be questioned or it could also legitimizing purpose in certain situations and the company therefore uses sustainability reporting to regain trust. Another common situation is when media is reporting negative and the company therefore tries to 
increase their positive aspect with the help of sustainability reporting. For a company to achieve legitimacy they can change their behaviours or practice or even be in doing more symbolic activities, like work with legitimate organisations, so that they can gain legitimacy without changing the company's behaviours [26]. Some state that sustainability reporting is used by companies more as a symbolic act with the aim to gain or maintain legitimacy [27]. There are several studies that state that sustainability reporting is mainly positive and there are few bad news reported (green-washing or self-laudatory) [28]. For these companies, sustainability reporting is more a symbolic action to gain legitimacy towards the stakeholders. The companies have not changed their behaviour concerning sustainability issues but is just trying to gain legitimacy among stakeholders.

\subsection{Stakeholder theory}

For a limited company there are several stakeholders that are interested in the company from different reasons. The stakeholder theory argue that the different stakeholders should be presented with different reports about the company like for instance sustainability information. The stakeholders is of course shareholders but also for instance banks, investors, customers, employees, government and suppliers. The report should be created so that the needs from stakeholders is addressed, but this might cause problems since different stakeholders might ask for different information. The company therefore need to prioritize and address based on how important they are often based on control over the money (maximize the revenues). There might also be different sources of information that the stakeholders' uses like annual reports, sustainability reports, homepages and printed materials. Nowadays, some companies has different goals and different information for different stakeholders. It might be profit, good working conditions, low prices, high quality, environmental concerns and social awareness. In that way might sustainability reports be an active strategic plan towards the stakeholders to show off a certain image. The annual reports if often focused on shareholders, banks and other credit actors meanwhile the sustainability report is often focused towards the customers. This is often a second group after the shareholders [4, 17].

\subsection{Accountability}

Accountability is focused on what a company is responsible for and what kind of information is provided to their stakeholders. The reason for sustainability reporting should be to present reliable and trustworthy accounts to the company's stakeholders on environmental and social activities. Gray [29] argue that from an accountability perspective that it should be mandatory to provide sustainable reports. Sustainability reporting is still a voluntary process but will during 2017 be mandatory within the European Union for companies with more than 250 employees, a yearly turnover over 35 million euro or total assets of 17, 5 million euro. The issue if it should be voluntary or mandatory is an issue discussed among accountability researchers. Companies that embrace sustainability reporting voluntary will benefit since it could be a competitive advantage. Sustainability reporting can help both stakeholders as well as the company [30]. Gray [29, p.181] 
argues that: "reporting almost never offers a complete picture of organisational activity, social responsibility reporting is exceptionally selective, sustainability reporting, despite protestations to the contrary is yet to address sustainability and accountability is not discharged." "The lack of regulation has been identified as a barrier to improving quality within the accountability literature arguing that while sustainability reporting remains a voluntary process, companies will not discharge accountability" [31]. Within accounting research, it has been stated that there exist an information gap between companies and its investors [32]. Companies have more information about its events and likely future performance [33]. It could also be that in the same way that there is an information gap on environmental issues between companies and its wider stakeholder group. It means that companies itself has more knowledge of its processes, products and wastes and have much more information on its environmental performance compared to its stakeholders. The company can therefore, since it is aware of all environmental consequences, choose whether and how to spread this information. Research have shown conflicting pictures if it reduce information asymmetry or not. Some researcher state that the benefits for investors was a main factor for environmental reporting as a strategy [34]. Previous research have shown that information asymmetry also have an impact on the quality of the reporting [35, $36]$. If the quality is higher is also reduces information asymmetry. To reduce an information gap higher quality of reporting is essential, another issue is than information asymmetry and sustainability reporting. The stakeholders that should read the sustainability reports might not be able to judge the quality of it. The opinion of Schaltegger [37] is that the information is useless if the reader does not understand its content. Companies must reduce the use of difficult language to make the information useful for the stakeholder and is must also be relevant information. It can be hard for that stakeholder to value the information and can therefore make wrong decisions because of incomplete information [37].

\section{Method}

This data for this study was collected mainly during December 2015- February 2016. The research design was constructed as a qualitative explorative study on tourism service providers and how they present their work with sustainability (economic, social and environmental) for stakeholders. The paper covers research results collected from 60 different random selected tourism service providers in Sweden (20 hotels, 20 restaurants and 20 activity companies). Data was collected in certain steps. First, we used the homepage www.allabolag.se that has all limited company in Sweden registered. We selected limited companies that was labelled as hotels and/or restaurants. Their yearly turnover was between 5-50 million euros (50-500 million SEK). We graded them according to largest size and selected the 20 hotels and 20 restaurants with highest turnover. We did the same way with activity companies but selected companies that was labelled as culture, entertainment and leisure. We ended up with companies that own ski areas, golf courses and entertainment parks. A few of our selected limited companies was labelled as hotel or restaurant but in their annual report it showed that the 
company's main activity was not within tourism. We therefore removed them and continued selecting from the list until we had 20 each for the three groups. Some of the company might have both a hotel and a restaurant within the hotel. In these cases have we labelled the company from its main income (mostly hotels). The European Union has, through directive 2014/95/EU, decided that larger companies must present a sustainability report from year 2017. The report should be based on guidelines from Global Reporting Initiative (GRI). It was therefore interesting to investigate these tourist companies since they are large and see what they are communicating concerning sustainability. We started with reading each company's annual report to see if and what kind of sustainability information was presented there. The second step was to search for each company's sustainability reports to see if they have one or not and what kind of information that was presented among those that make sustainability reporting. The last step was to investigate their homepages to again see if they have any sustainability information and in that case what kind of information. All data was therefore secondary data from written documentation from the tourism service providers. The written documentation was from annual reports, sustainability reports and home pages. This means that the data was also collected from several sources. The data was divided into different categories and then analysed with an interpreted approach based on the areas presented within the GRI framework. The three sustainability dimensions (themes) was also divided into sub-themes. In table 1 we present the different themes that is used in the analysis. In the interpretative analysis we were trying to make sense of the collected data [38]. Sense making is a process which can be successfully used in research. Here this concept is used to understand and make sense of sustainability reporting among tourism service providers. If a tourism service provider state in their annual report, or/and sustainability reports or/and on their homepage that they are working with sustainability issues they probable do. We suspect that we would have gotten a similar result if we would have conducted interviews instead (this would be interesting for further research). The only true way knowing the reality is do actually take part of their practical work. They might show a better picture then the reality (to be a good company since sustainable tourism is for most people something good) of the tourism service provider but it that sense it is the same for all selected cases.

\section{Findings and discussion}

The result from this study is not aiming to be used for generalization but rather a first step in an interesting research field that needs to be further examined. The discussion about sustainable tourism has been long and the result fairly limited so far among tourism service providers. Sustainable tourism consist of contradictions where there should be economic growth and at the same time preservation both concerning social and environmental sustainability. All 60 tourism service providers must have economic sustainability which is shown for stakeholders in the annual reports that is audit by accountants. The focus in this paper is instead what kind of sustainability factors are addressed by tourism service providers in 
information to their stakeholders with a focus on social and environmental issues. Only two of the 60 tourism companies do sustainability reports and they are both hotels. These two companies present to a large extent much information to their stakeholders. According to the framework of GRI there are aspects concerning social and environmental sustainability that can be addressed. In the companies that present information about their social sustainability there is only two of the five areas that is addressed; employment and then diversity and equality. There is a large focus on equality both from gender perspective as well as multicultural perspective. It is mainly restaurants that focus on social sustainability. The factors from GRI concerning environmental issues are addressed mostly by hotels. Few of the hotels present, in their annual reports, sustainability issues except for financial numbers. Five from the twenty hotels address other sustainability issues in short sentences and the main focus is on environmental sustainability. There is a focus on different kinds of labels that they use at their hotels. Two of the hotels have sustainability reports. Many of the hotels have structured their sustainability on a label like "ISO14001", "Green key" and "The swan". For almost all activity companies they are highly dependent on the nature, the nature is a key resource for their tourism product, it is therefore interesting to see how important sustainable issues are, or even worse - how unimportant it seems to be. They do not have almost information about their sustainability work despite that nature is the core of their product. A ski resort needs the snow, a golf course needs the grass but museums and fun parks are constructed places that is not highly dependent on the nature the same way.

The result from this study show that there are difference between the different types of tourism service providers. It is therefore interesting to discuss who is the stakeholder that they are aiming there information to? The information is presented to show accountability and legitimacy concerning sustainability to stakeholders. The information about sustainability on the homepages is mainly targeting the customers. There were differences between the homepages but the selected companies had enough information concerning sustainability which made it possible to compare them.

\section{Conclusion}

The conclusion is that sustainable tourism is still not an aim that all tourist service providers is focused on. There is very little information in their annual reports and very few have sustainability reports. Most of the communication to stakeholder about their sustainability work is performed to home pages. The information is common and cannot be said to address one type of stakeholders in particular. The aim with this study was to explore and compare what kind of information concerning sustainability that Swedish tourism service providers' present to stakeholders. The result show that they are focused on different aspects of sustainability depending on what kind of tourism service they offer. The hotels are mainly focused on environmental issues and those that seems to work more do often use an environmental label like "ISO14001", "Green key" and "The swan". The restaurants on the other hand are focused both on social sustainability and 
environmental sustainability. The social sustainability is often concerning social initiatives for sick, poor or exposed people. The focus is not on the employees' social issues. The restaurants differ in their sustainability communication. There is one group that mention their sustainability work is a short sentence or paragraph like that their coffee is Fairtrade labelled. The other group of restaurants have a lot information for the stakeholders. The activity companies are not presenting almost anything about their sustainability work to their stakeholders.

For further research it would be interesting to conduct interviews with the companies to gain more insight in what they want to communication and why concerning sustainability to their stakeholders. This study included a group of tourism service providers in Sweden and it would be interesting to compare with other countries and culture concerning tourist companies' sustainability work and their communication to stakeholders.

\section{References}

[1] Brundtland, G. (chair). Report of the World Commission on Environment and Development: Our Common Future (WCED). New York: Oxford University Press, 1987.

[2] The global reporting initiative, https:/www.globalreporting.org/standards /G3andG3-1/guidelines-online/G3Online/Pages/default.aspx, 2016-03-16.

[3] Mahoney, L. S., Thorne, L., Cecil, L., \& LaGore, W. A research note on standalone corporate social responsibility reports: Signaling or greenwashing? Critical Perspectives on Accounting, 24(4), 350-359, 2013.

[4] Dumay, J., Guthrie, J., \& Farneti, F. GRI sustainability reporting guidelines for public and third sector organizations: A critical review. Public Management Review, 12(4), 531-548, 2010.

[5] Sweeney, L., \& Coughlan, J. Do different industries report corporate social responsibility differently? An investigation through the lens of stakeholder theory. Journal of Marketing Communications, 14(2), 113-124, 2008.

[6] Dumay, J., Guthrie, J., \& Farneti, F. GRI sustainability reporting guidelines for public and third sector organizations: A critical review. Public Management Review, 12(4), 531-548, 2010.

[7] Buchholz, R. A., \& Rosenthal, S. B. Toward a contemporary conceptual framework for stakeholder theory. Journal of Business Ethics, 58(1-3), 137148, 2005.

[8] Dilling, P. F. Sustainability reporting in a global context: What are the characteristics of corporations that provide high quality sustainability reports - an empirical analysis. The International Business \& Economics Research Journal, 9(1), 19, 2010.

[9] Hahn, R., \& Kühnen, M. Determinants of sustainability reporting: a review of results, trends, theory, and opportunities in an expanding field of research. Journal of Cleaner Production, 59, 5-21, 2013.

[10] Lozano, R., \& Huisingh, D. Inter-linking issues and dimensions in sustainability reporting. Journal of Cleaner Production, 19(2), 99-107, 2011. 
[11] Garrod, B. Fyall, A. Beyond the rhetoric of sustainable tourism? Tourism management. Vol. 19, no. 3, pp. 199-212, 1998.

[12] Clarke, J. A Framework of Approaches to Sustainable Tourism. Journal of Sustainable Tourism. Vol, 5. No, 3. pp. 224-233, 1997.

[13] Liu, Z. Sustainable Tourism Development: A Critique. Journal of Sustainable Tourism. Vol, 11. No, 6. pp. 459-475, 2003.

[14] Sharpley, R. Tourism and Sustainable Development: Exploring the Theoretical Divide. Journal of Sustainable Tourism. Vol, 8. No, 1. pp. 1-19, 2000.

[15] Saarinen, J. Traditions of sustainability in tourism studies. Annals of Tourism Research. Vol, 33. No, 4. pp. 1121-1140, 2006.

[16] Wall, G. Sustainable development: political rhetoric or analytical construct. Tourism Recreation Research. Vol, 27. No, 3. pp. 89-91, 2002.

[17] Waligo, V. Clarke, J. Hawkins, R. Implementing sustainable tourism: A multi-stakeholder involvement management framework. Tourism Management, Vol 36, pp. 342-353, 2013.

[18] Sörensson, A. Sustainable tourism at mass tourist destinations: best practice from tourism service providers in Europe. Brebbia, C.A. (ed). The Sustainable World. Southampton: WIT Press, 2010.

[19] Buhalis, D. Fletcher, J. Environmental impacts on tourist destinations: an economic analysis. Coccossis, H. \& Nijkamp, P. (ed). Sustainable Tourism Development. Hants: Avebury, 1995.

[20] Elkington, J. Cannibals with forks. The triple bottom line of 21 st century, 1997.

[21] The global initiative reporting, https:/www.globalreporting.org/ resourcelibrary/GRI-An-introduction-to-G4.pdf, 2016-02-22

[22] Hooghiemstra, R. Corporate communication and impression managementnew perspectives why companies engage in corporate social reporting. Journal of business ethics, 27(1-2), 55-68, 2000.

[23] Suchman, M. C. Managing legitimacy: Strategic and institutional approaches. Academy of management review, 20(3), 571-610, 1995.

[24] Bansal, P., \& Clelland, I. Talking trash: Legitimacy, impression management, and unsystematic risk in the context of the natural environment. Academy of Management Journal, 47(1), 93-103, 2004.

[25] Dowling, J., \& Pfeffer, J. Organizational legitimacy: Social values and organizational behavior. Pacific sociological review, 122-136, 1975.

[26] Buhr, N. Environmental performance, legislation and annual report disclosure: the case of acid rain and Falconbridge. Accounting, Auditing \& Accountability Journal, 11(2), 163-190, 1998.

[27] Hooghiemstra, R. Corporate communication and impression managementnew perspectives why companies engage in corporate social reporting. Journal of business ethics, 27(1-2), 55-68, 2000.

[28] Ratanajongkol, S., Davey, H., \& Low, M. Corporate social reporting in Thailand: The news is all good and increasing. Qualitative Research in Accounting \& Management, 3(1), 67-83, 2006. 
[29] Gray, R. Taking a long view on what we now know about social and environmental accountability and reporting, Issues in Social \& Environmental Accounting, 1 (2007), pp. 169-198, 2007.

[30] Unerman, J., \& O'Dwyer, B. The business case for regulation of corporate social responsibility and accountability. In Accounting Forum (Vol. 31, No. 4, pp. 332-353). Elsevier, 2007.

[31] Comyns, B., Figge, F., Hahn, T., \& Barkemeyer, R. Sustainability reporting: The role of "Search", "Experience" and "Credence" information. In Accounting Forum (Vol. 37, No. 3, pp. 231-243). Elsevier, 2007.

[32] Milgrom, P. R. Good news and bad news: Representation theorems and applications. The Bell Journal of Economics, 380-391, 1981.

[33] Healy, P. M., \& Palepu, K. G. Information asymmetry, corporate disclosure, and the capital markets: A review of the empirical disclosure literature. Journal of accounting and economics, 31(1), 405-440, 2001.

[34] Cormier, D., \& Magnan, M. Environmental reporting management: a continental European perspective. Journal of Accounting and Public Policy, 22(1), 43-62, 2003.

[35] Brown, S., \& Hillegeist, S. A. How disclosure quality affects the level of information asymmetry. Review of Accounting Studies, 12(2-3), 443-477, 2007.

[36] Healy, P. M., \& Palepu, K. G. Information asymmetry, corporate disclosure, and the capital markets: A review of the empirical disclosure literature. Journal of accounting and economics, 31(1), 405-440, 2001.

[37] Schaltegger, S. (1997). Information costs, quality of information and stakeholder involvement-the necessity of international standards of ecological accounting. Eco-Management and Auditing, 4(3), 87-97.

[38] Weick, K. Making Sense of the Organization. Cornwall: Blackwell Business, 2001. 